\title{
Evaluation of the Parameters Affecting Passenger Riding Comfort of a Rail Vehicle
}

\section{Mária Loulová, Andrej Suchánek, Jozef Harušinec}

Faculty of Mechanical Engineering, University of Zilina, Univerzitná 8215/1, 01026 Žilina. Slovak Republic. E-mail: maria.manurova@fstroj.uniza.sk, andrej.suchanek@fstroj.uniza.sk,jozef.harusinec@fstroj.uniza.sk.

The effort to increase the rail vehicle ride speed on existing tracks, or more precisely on modernized tracks with a lot of curves with a relatively smaller radius, lead to use of tilting mechanism of the vehicle body. The paper deals with simulation analysis of a rail vehicle with an active tilting system of the vehicle body, design of the rail vehicle in CAD program CATIA and dynamical analysis in program SIMPACK, with the RAIL expansion. Such body mounting on vehicle bogies is significantly more complicated than the design of conventional rail vehicles. The purpose of this type of body mounting is to increase the size of body tilt during ride in a curve and thus reduce the lateral unbalanced acceleration affecting the passengers, or allow higher driving speed in a curve with the same radius while keeping the lateral acceleration value respectively. Eight variants of different velocity, vehicle occupancy and setting of the tilting mechanism were analyzed. We determined the average value of passenger comfort $N_{M V}$ from the simulation results. We have determined the value of passenger comfort during the ride in a curve $P_{C T}$ from the simulation results.

Keywords: Passenger comfort, Dynamical model, Tilting mechanism, SIMPACK

\section{Acknowledgement}

This paper was created during the processing of the project "RAILBCOT - RAIL Vehicles Brake COmponents Test Stand", ITMS Code 26220220011 based on the support of Research and Development Operational Program financed by European Fund of a Regional Development. The work was also supported by the project No. APVV-0842-11: "Equivalent railway operation load simulator on the roller rig". Research-Educational Center of Rail Vehicles (VVCKV)

\section{References}

[1] DIŽO, J., BLATNICKÝ, M., SKOČILASOVÁ, B. (2015). Computational modelling of the rail vehicle multibody system including flexible bodies. In: Communications: scientific letters of the University of Žilina. ISSN 13354205. - Vol. 17, no. 3 (2015), s. 31-36. (In Slovak)

[2] DIŽO, J. (2015). Evaluation of ride comfort for passengers by means of computer simulation In: Manufacturing technology. ISSN 1213-2489. Vol. 15, no. 1 (2015), s. 8-14.

[3] DIŽO, J., GERLICI, J., LACK, T. (2013). The passenger car ride comfort assessment by means of ADAMS/Rail software utilization. In: TRANSCOM 2013: 10-th European conference of young researchers and scientists: Žilina, ISBN 978-80-554-0695-4. S. 67-70.

[4] FOMIN, O. (2014) Modern requirements to carrying systems of railway general-purpose gondola cars. Scientific and technical journal. Metallurgical and Mining Industry. 2014, No. 5 - P.31-43.

[5] GERLICI, J. (2013). Comfort for passengers of rail vehicle assessment. In: Advanced methods in computational and experimental mechanics. London: Pearson Education Limited, 2013. ISBN 978-1-78434-069-8. (pp. 141172).

[6] GERLICI, J., LACK, T. (2007). Methods for vehicle vibration analysis in time domain. In: Prace Naukowe. Transport. ISSN 1230-9265. Z. 63 (2007), (pp. 71-81).

[7] GERLICI, J., LACK, T. (2009). Railway wheel profile development based on the geometric characteristics shapes. In: Contact mechanics and wear of rail/wheel systems = CM2009: 8th international conference: Italy: AB EDITORE, 2009. ISBN 978-88-904370-0-7, (pp. 961-967).

[8] GERLICI, J., LACK, T. (2011). Railway wheel and rail head profiles development based on the geometric characteristics shapes. In: Wear: an international journal on the science and technology of friction, lubrication and wear. ISSN 0043-1648. - Vol. 271, No. 1-2 Sp. iss. (2011), (pp. 246-258).

[9] GERLICI, J., LACK, T. (2003). Rail geometry analysis (from the point of view of wearing in the operation). In: Communications - scientific letters of the University of Žilina. ISSN 1335-4205. Vol. 5, No. 1 (2003), (pp. 43-51).

[10] GERLICI, J., LACK, T. (2008). Modified HHT method usage for vehicle vibration analysis in time domain. In: Communications - scientific letters of the University of Žilina. ISSN 1335-4205, 2/2008, (pp. 26-32).

[11] GERLICI, J., LACK, T. (2014). Modified HHT method for vehicle vibration analysis in time domain utilisation. In: Applied Mechanics and Materials. ISSN 1660-9336. Vol. 486 (2014), online ISSN 1662-7482, Trans Tech Publications, Switzerland, (pp. 396-405). 
[12] GERLICI, J., LACK, T. (2004). The Rail - Wheel contact. University of Žilina, ISBN 80-8070-317-5. (p. 200). (In Slovak)

[13] GERLICI, J., LACK, T. et all. (2005). Transport means properties analysis: Volume 1 (2005) - 1st ed. - Žilina: University of Žilina, 2005. (p. 214), ISBN 80-8070-408-2.

[14] GERLICI, J., LACK, T., LACKOVÁ, M. (2004). Calculation of the equivalent conicity function of the railway wheelset tread profile at the Delta R function with a negative slope. In: Communications: Scientific Letters of the University of Žilina. ISSN 1335-4205. - Vol. 6, Nr. 2 (2004), (pp. 49-56).

[15] HAUSER, V. (2015) Rail-wheel contact of tramways vehicles in arc track. In: TRANSCOM 2015: 11. European conference of young researchers and scientists: ISBN 978-80-554-1048-7. S. 64-69.

[16] KRAVCHENKO, E., GORBUNOV, N., SOSNOVENKO, S., PROSVIROVA, O., BRAGIN, N., (2012) Influence of locomotive operating characteristics on wheels in contact with the rails. In: Teka. Commission of motorization and energetics in agriculture. 2012. Vol. 12, No. 4, Pp. 108-112.

[17] LACK, T., GERLICI, J. (2008). Analysis of vehicles dynamic properties from the point of view of passenger comfort. In: Communications: Scientific Letters of the University of Žilina. Vol. 10, No. 3 (2008), p. 10-18. ISSN $1335-4205$.

[18] LACK, T. GERLICI, J. (2007). Vehicles Dynamical Properties Analysis from the Point of View of Comfort for Passengers. In: Proc. Archives of Transport. Warszawa: 2007. Vol. 19, Issue 1-2, Pp. 91-110. ISSN 8066-9546.

[19] LACK, T., GERLICI, J. (1997). Vibrational analysis of mechanical system with concentrated masses. (In Slovak). In: Current problems in rail vehicles: 13. International conference. ISBN 80-7194-105-0, (pp. 263-271).

[20] LACK, T., GERLICI, J. (2013). Tangential stresses for non-elliptical contact patch computation by means of modified FASTIM method. In: IAVSD 2013: 23rd international symposium on dynamics of vehicles on roads and tracks: China: Southwest Jiaotong University, (p.6).

[21] LACK, T., GERLICI, J. (2014). Wheel/rail tangential contact stress evaluation by means of the modified strip method. Communications: Scientific Letters of the University of Žilina. Vol. 16, No. 3A (2014), Pp. 33-39. ISSN $1335-4205$.

[22] LACK, T., GERLICI, J. (2013). The FASTSIM method modification in speed up the calculation of tangential contact stresses between wheel and rail. In: Manufacturing technology: journal for science, research and production. ISSN 1213-2489. - Vol. 13, no. 4 (2013), (pp. 486-492).

[23] LACK, T., GERLICI, J. (2012). Modified Strip Method utilisation for wheel/rail contact stress evaluation In: 9th international conference on contact mechanics and wear of rail/ wheel systems (CM2012) : 27-30 August 2012, Chengdu, China : proceedings. Session 5: Fundamental contact mechanics. - Chengdu: Southwest Jiaotong University, 2012. - Pp. 87-89.

[24] LACK, T., GERLICI, J. (2014). A modified strip method to speed up the calculation of normal stress between wheel and rail. In: Applied mechanics and materials. ISSN 1660-9336. Vol. 486 online ISSN 1662-7482. Trans Tech Publications, Switzerland, (pp. 359-370).

[25] LACK, T., GERLICI, J. (2014). A modified strip method to speed up the tangential stress between wheel and rail calculation. In: Applied mechanics and materials. ISSN 1660-9336. Vol. 486 online ISSN 1662-7482. Trans Tech Publications, Switzerland, (pp. 371-378).

[26] LACK, T., GERLICI, J., ONDROVÁ, Z. (2007). Evaluation of comfort for passengers of railway vehicles. In: Communications: Scientific Letters of the University of Žilina. Vol. 9, No. 4 (2007), pp. 44-49. ISSN 1335-4205.

[27] MAŇUROVÁ, M., SUCHÁNEK, A. (2016). The simulation analysis of a rail vehicle with a tilting bogie. In: IIIth conference. Experimental and computational methods in Engineering. ISBN 978-80-7561-004-1. (In Slovak)

[28] STN EN 12299:2009. Railway applications. Ride comfort for passengers. Measurement and evaluation. 2009.

[29] SIMPACK A.G. (2014). Documentation to the program system SIMPACK.

[30] SKOČILAS, J., SKOČILASOVÁ, B., SOUKUP, J. Determination of the rheological properties of thin plate under transient vibration. Latin American Journal of Solids and Structures. Brasil society for mechanics and engineering. ISSN 1679-7817 (print), 1679-7825 (online).

[31] SMETANKA, L., GERLICI, J., LACK, T., PELAGIĆ, Z. (2015) Homogenization of fibers reinforced composite materials for simulation analysis. In: Manufacturing technology: journal for science, research and production. ISSN 1213-2489. Vol. 15, no. 5 (2015), s. 914-920.

[32] SVOBODA, M., SOUKUP, J. (2013). Dynamic measurement of four-axle railway wagon. In: Manufacturing Technology. 2013, vol. 13, iss. 4, (pp. 552-558). ISSN 1213-2489.

[33] ŠŤASTNIAK, P. (2015) Freight long wagon dynamic analysis in S-curve by means of computer simulation. In: Manufacturing technology: ISSN 1213-2489. - Vol. 15, no. 5 (2015), s. 930-935.

Paper number: M201741

Copyright (C) 2017. Published by Manufacturing Technology. All rights reserved. 